\section{The Hebrew adverbial bixlal}

\section{O advérbio hebraico bixlal}

Ruti BARDENSTEIN (The Tel-Aviv University Israel) ruti.bardenstein@gmail.com
BARDENSTEIN, Ruti. The Hebrew adverbial bixlal. Entrepalavras, Fortaleza, v. 6, n. 2, p. 10-28, jul./ dez. 2016.

Abstract: The Modern Hebrew adverbial bixlal (at all/any/actually/in fact/even/ anyway/in general/generally/altogether/ in the first place) seems puzzling from a synchronic point of view since it functions both as a NPI lo...bixlal/bixlal lo (not...any/at all) and as a Discourse Marker(DM) in positive environments ${ }^{1}$, being interpreted either as an 'in general' DM when focused (stressed) or as an 'actually' DM when unfocused (unstressed). As a result, it has been the focus of various papers examining both its semantics and discursive use (Migron 2003, Ziv 2012, Greenberg and Khrizman 2012, Kadmon and Sevi, 2014, as well as its possible grammaticization path (Tsirkin-Sadan 2015). The Solution that we offer is that bixlal is a polysemy and its multiple meanings difference can be explained diachronically. We shall provide historical evidence as well as provide bridging examples which explain the shift from one stage to another down the grammaticization path.

Keywords: Usage-Based Grammar. Grammaticization. Negative Polarity items (NPI).

1 We define DMs as operators which argumentatively predict the elements that follow them in the discourse. 
Resumo: No hebraico moderno, o advérbio bixal (de todo / qualquer / realmente / de fato / mesmo / de qualquer maneira / em geral / geralmente / completamente / em primeiro lugar) parece enigmático de um ponto de vista sincrônico, vez que funciona tanto como um Item de Polaridade Negativa (IPN) lo...bixlal/bixlal lo (não...somente/ de nada) quanto como um Marcador Discursivo (MD) em contextos positivos, sendo interpretado como um MD "em geral", quando focalizado (enfatizado prosodicamente) ou como um MD "de fato", quando desfocado (sem ênfase). Como resultado, tem sido foco de vários artigos, que examinam a sua semântica e uso discursivo (MIGRON, 2003, ZIV, 2012, GREENBERG; KHRIZMAN 2012, KADMON; SEVI, 2014), bem como o seu possível percurso de gramaticalização (TSIRKIN-SADAN, 2015). A solução que nós oferecemos é que o bixlal é uma polissemia e a diferença de seus significados múltiplos pode ser explicada diacronicamente. Proveremos provas históricas, bem como forneceremos exemplos de bridging (ambíguos) que explicam a mudança de um estágio para outro no percurso de gramaticalização.

Palavras-chave: Gramática baseada no uso. Gramaticalização. Item de Polaridade Negativa (IPN).

\section{Introduction}

In this paper, we argue for two main claims regarding the grammaticization path of the Hebrew adverbial bixlal, which have led to its polysemous nature:

A. bixlal's semantic change is motivated pragmatically via the operator's widening function. bixlal functions as a widening operator, since its very early occurrence in the Mishnah (3rd century) to its use in Modern Hebrew.

B. We shall argue that a frequent occurrence of bixlal within the rectification construction 'lo $\mathrm{x}$, ela $\mathrm{y}$ ' in Hebrew ('not $\mathrm{x}$, but $\mathrm{y}$ ') created a strong association between this adverbial and the function of rectification, which paved the way for a dramatic semantic change, turning it into a rectification marker. Once reinterpreted as a rectification marker, it can be used to indicate rectification even in the absence of the complete construction. In other words, the rejected content $(\mathrm{X})$ within the construction: 'bixlal lo $\mathrm{x}$, ela y' ('at all not $\mathrm{x}$, but $\mathrm{y}$ '), which is contextually accessible, is negated in a predictable way, based on the rectification marker bixlal, which gradually 'took on negation', since it was so often used as a Negative Polarity Item (NPI) in rectification constructions ${ }^{2}$. The reduced construction ('compactization') in which bixlal has become a rectification marker is exemplified in (1):

2 NPIs (see LADUSAW, 1996) are negation strengthening operators, which strengthen the original negation operator and can appear in environments associated with a particular grammatical polarity of negation. 


\section{v. 6 (2)}

10-28

jul/dez

2016
(1)

A: 'bixlal loX, elaY' ('at all not X, but Y')

$>$ Compactization:

B: 'bixlal Y' (interpreted as 'not at all $\mathrm{X}$ but Y').

Though the claim that the operator bixlal has taken on negation seems somewhat dramatic, there are many similar cases discussed in the literature, mainly those of Jespersen (1917). Jespersen introduced the Jespersen's Cycle (JC), a term coined by Dahl (1979). The JC is a series of syntactic processes of change which describe the historical development of the expression of negation in a variety of languages, from a simple pre-verbal marker of negation, through a discontinuous marker. (elements both before and after the verb) and in some cases through subsequent loss of the original pre-verbal marker:

The history of negative expressions in various languages makes us witness the following curious fluctuation: the original negative adverb is first weakened, then found insufficient and therefore strengthened, generally through some additional word, and this in turn may be felt as the negative proper and may then in the course of time be subject to the same development as the original word. (JESPERSEN, 1917, P.4).

Jespersen has called this kind of operation "negative attraction" and has discussed various negative expressions in various languages. The most cited one is the case of French pas, originally meaning 'step'. In its initial stage, pas had been used as a NPI with the verb 'walk' ('I don't walk/ do a step') and later on it has broadened its use as a more general NPI, strengthening other negated verbs such as 'know': je ne sais pas ('I don't know anything'), or 'say': je ne dis pas ('I don't say anything'). Later, the NPI has been 'bleached' (weakened) thus creating a strong association between negation and the NPI pas, which gradually became part of the negation operation: 'je ne sais pas' ('I don't know'). In addition, pas (In colloquial French) has gone through the cycle in which the explicit negation operator ne has become only optional, since pas has been so strongly associated with the negation: je sais pas ('I don't know'). Lastly, as exemplified in (2), pas had become an operator of negation itself and can be used to operate independently as a negation operator. 
(2)

Je n'ai meme pas ('I didn't walk/take a step')

I

Je ne sais pas ('I don't know anything')

II

Je ne sais pas ('I don't know')

$\downarrow$

Je n'ai meme pas pu faire un pas ('I didn't walk, not even a step')

III

Je sais pas $\longrightarrow$ J'sais pas ('I don't know')

IV

pas possible ('not possible')

\#pas possible pas

In stage II above, the negative operator ne collaborates with pas as to mark negation. We claim this is crucial for pas to become the negative operator itself. We call this stage "merging". A construction in which the explicit negation operator + the NPI frequently co-occur, thus allowing for "merging" to happen and later for the NPI to become the negative operator itself. Interestingly, unlike the notion of a "preverbal" negation operator becoming a "post verbal negation operator", we claim that the focus of attention should be given to the NPI itself and not the negation operation as a whole. Thus, the post-verbal NPI's collaboration with the negation might precede some non-motion verbs, as can be observed in (3):

(3) Ne pas être fier ('don't be proud')

Though pas' transformation into a negation marker is not complete, (since it often cannot scope over motion verbs), it can, however, occur pre-predicatively, as in stage IV above, or (along with the negation marker ne), pas can occur pre-non motion verbs, as in (3). pas also cannot be used in the same utterance for the two different functions (once as the negation operator and once as a NPI), as shown in stage IV. Although pas can operate as the negation operator along with another (different) NPI, it cannot occur with the pas as a NPI.

In Spoken Palestinian Arabic (SPA), a somewhat similar process 
v. 6 (2)

10-28

jul/dez

2016

is revealed with the NPI iši ('thing') 3. However, as exemplified in (4), the grammaticalization path of iši is somewhat different than that of French pas and might be perceived as 'more progressed', mainly due to the fact that SPA iši has turned into a verbal suffix š, unlike French pas, which hasn't gone through similar phonological changes and cannot modify most French verbs:

(4)

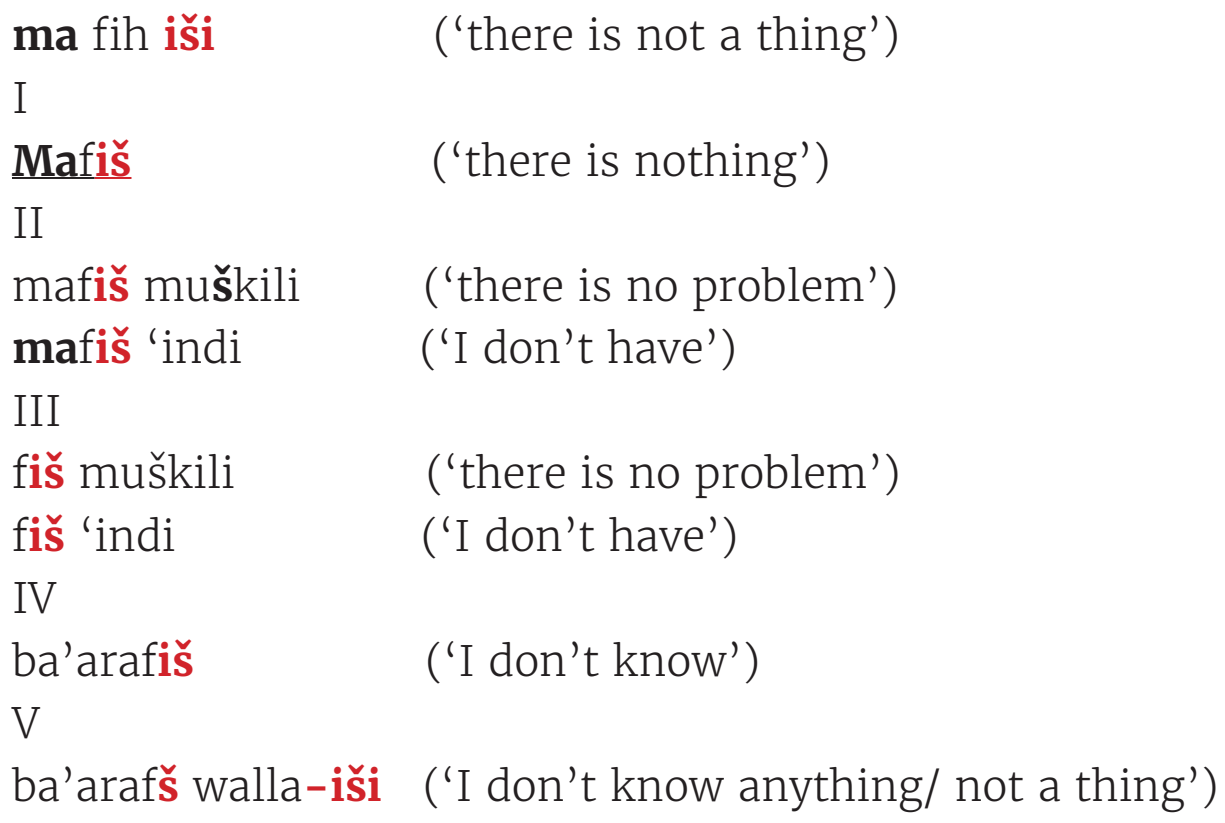

Once again, the notion of 'pre-verbal' or 'post verbal' seems redundant. It is more about the transformation of iši ('thing') from a noun, into a NPI and later as a negation operator, which has become part of the verb itself in SPA (as a suffix morpheme š), rather than a 'post-verbal negation operator'.

We shall argue that in the case of bixlal, bixlal has evolved dramatically since its first occurrence in the Mishnah (Rabbinic Hebrew) since it was used as a NPI around the 19th century, later "taking on negation" within the rectification construction, thus transforming it into a rectification marker in the discourse (a rectification DM). In addition, in the case of bixlal, it has become a sentential adverbial negation operator and therefore can 'freely precede verbs'. Let us now examine bixlal in its initial stage: 


\section{Stage I: PP head- 'be/ba-klal': "In the rule"}

Bixlal, originally pronounced $b a / b e-k l a l$, is not a biblical word. It first appears in the Mishna ( $3^{\text {rd }}$ century) as a PP head which is composed of the preposition - be/ba ('in') and the noun klal ('rule'). Its meaning is therefore: 'in (the) rule', often interpreted as 'as part of all' or 'included in the category' as in (5):

\section{(5) še-had-delo'in be-klal yarak that-the-gourds in-rule-of vegetables \\ 'Gourds are included in the category of vegetables' [Mishna, Nedarim 7a]}

In Rabbinic Hebrew, the Mishnah (the "oral Torah"), actually includes a variety of laws that the Jewish man or woman way adopt and obey. Amongst those rules are the categorizations of what is considered a fruit and what is considered a vegetable. In (5) above, the Halachic law is of what is considered a vegetable and states that gourds are included in the category of vegetables according to the rule. biklal's function here is thus to widen a category to which a Halachic law applies, (TSIRKIN-SADAN, 2015; GREENBERG; KHRIZMAN, 2012), since once adding another member to the category of vegetables, it actually widens. This use is also evident (more or less in the same way), in the Babylonian and Jerusalem Talmud, around the $5^{\text {th }}$ century, such as with the inclusive until as shown in (6):

(6) 'ad 'etsem ha-yom heze [..] 'ad ve-'ad bekklal Until bone DEF-day this [..] until and-until in the rule

'Until this very day, including this very day' [Babylonian Talmud, Suka 3]

\section{Stage II: adverb biklal: "in general"}

In Medieval Hebrew (15 $5^{\text {th }}$ century) biklal is a PP-derived adverb, meaning "in general". It is included in constructions of biklal u-bifrat ('in general and in particular') and in its early tended to modify phrases, rather than full clauses, as in (7) (TSIRKIN-SADAN, 2015): 
V. 6 (2)

10-28

jul/dez

2016
(7) ha-leb hu 'iqar qiyum ha-ba'al-xay ve-hu kli

'The-heart he core existence of the living organism and is a vessel

Lehagia ha-xayut' el kol ha-'avarim biklal

to make arrive the life to all the body parts in-general

ve-la-moax bifrat

and-to the-brain in-particular'

[Rabbi Yosef Albo, sefer ha- 'ikarim, A:6, Spain, 15th Century]

We argue that biklal can be interpreted in (7), which is a bridging example, as in its original meaning. However, this interpretation is only left for inference. Thus, we shall argue that the explicature of (7) is in fact $(7 a)^{4}$ :

(7a) haleb hu ...kol ha-'avarim biklal [evarey guf ha'adam] ve- la-mo'ax bifrat.

'The heart is.. all organs included [in the organs of the human body] and the brain in particular'

4 The term explicature was coined by Sperber \& Wilson (1986) in Relevance Theory to characterize 'an explicit assumption in the discourse, based on Grice's implicature.

In other words, (7a) was originally stated explicitly and was later left for inference. This is probably because of the frequent use of biklal in the fixed construction (Goldberg 1995), along with bifrat ('in particular'), with which biklal has a category-specimen relations (SEVI; KADMON. 2014)5. Within those construction, it can be said that biklal had "taken on generalization", which no longer requires the cooccurrence of all and biklal.

In the $18^{\text {th }}$ century and early $19^{\text {th }}$ century, biklal was still used as a sentential adverbial (scoping over full clauses, rather than just phrases).

However, it no longer depended on its following binding within the construction 'biklal u-prat'. It is used independently, as shown in (8).

\section{(8) Eixut ha-gšamim bixlal}

5 Sevi \& Kadmon discuss the Modern use of this construction, which was inherited in Revival Hebrew. 
'The quality of the rains IN GENERAL

[Hame'asef, October $16^{\text {th }}, \mathbf{1 8 0 8}$ ]

We argue that the widening function here too leads to a categorical widening. Bixlal at this stage indeed includes a categoryspecimen relation, but still functions as a widening operator. This widening operation is what pragmatically drives the change.

\section{Stage III: NPI bixlal: "at all"|"altogether"|"any"}

With Revival Hebrew (RH) (late $19^{\text {th }}$ century), all of bikal's previous uses were inherited into $\mathrm{RH}$ but it had been phonologically changed and has been pronounced bixlal. This is due to Eli'ezer Ben Yehuda's work in reviving the spoken Hebrew language (which was not spoken for approximately 2,000 years and existed only within written religious texts (The bible, Mishnah, Talmud etc.). The following graph (1) shows bixlal's interaction with the negation operator lo (up until then it only occurred within constructions of negation in Halachic laws, mostly with the existential negation operator 'ein ('there is not'/'you cannot'), as shown in (9)), and we do not find evidence for the adjacency of bixlal and lo prior to mid-end of the $19^{\text {th }}$ century.

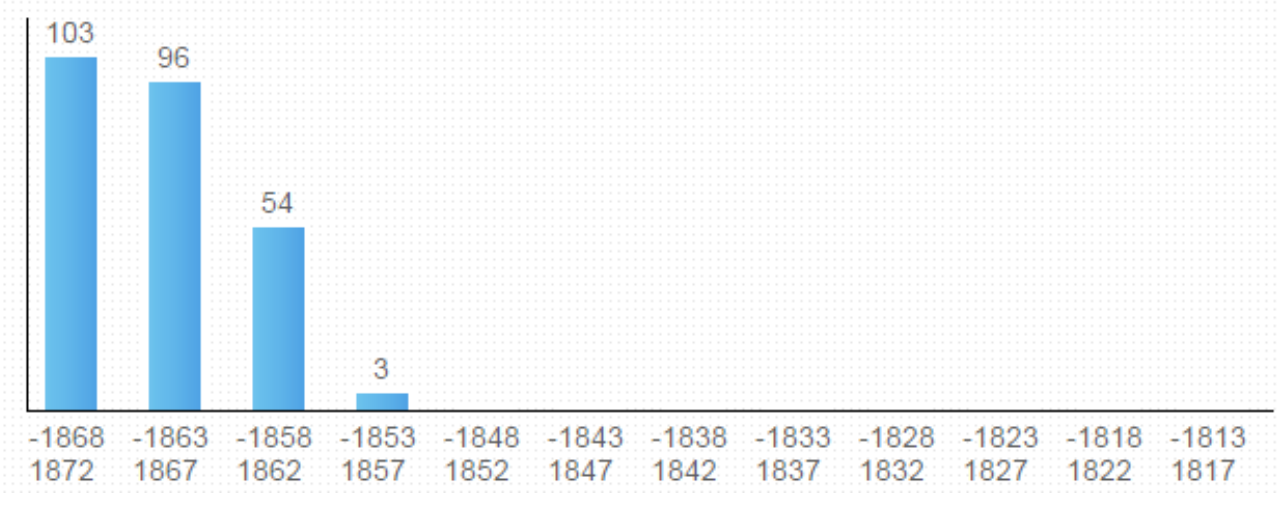

Graph 1 - Number of occurrences bixlal lo, in years

Taken from: National Library of the Tel-Aviv University site

(9) ve ha-kitnit eino bi-klal yarak and DET-legume NEG in-rule-of vegetables

'Legume is not included in the category of vegetables'

[Mishna, Nedarim 7a]

As evident in (1), it is only around the late $19^{\text {th }}$ century that bixlal lo ('not at all'/not any'/'actually not') had emerged. This historically 
v. 6 (2) $10-28$ jul/dez 2016

Still a sentential adverbial, bixlal at this stage can precede the negation operator and widens the scope of an accessible 'discursive negation' (either existential or not), therefore strengthening it ${ }^{6}$.

Now, let us focus on example (10). The widened negation with bixlal could be interpreted in two ways:

6 We shall define 'strengthening of discursive negation' as one of three cases:

(a) Strengthening of a previous negation in the discourse, as in (11)

(b)Strengthening of a 'commonly sloppy' negation use, as in (12)

(c) Strengthening of a rejection of a common-ground assumption, as in (13).

(A) Ein li kesef le'orex din ve-ein li kesef BIXLAL

'I don't have money for a lawyer and I don't have money AT ALL'

[Law guide, 29.12.12]

In (A), the speaker says: 'I don't have money for a lawyer'. Now, it could have been the case that the speaker (a divorcing father) would have money for other things which are 'not a lawyer'. Therefore, by using the second widened negation 'I don't groceries', 'not for clothes' etc.)

Example (B) is a scenario in which Ruti (the mother) has a $2 \$$ bill in her purse, but uses the negation 'sloppily' since she is only rejecting the fact that she has enough money for the movies?

(B) Avishai: 'ima, ani tsarix kesef leseret hayom

Avishai: "Mom, I need money to the movies tonight"

Ruti: 'Ein li kesef'

Ruti: "I don't have money"

[Casual conversation, 14.12.15],

When using a widened negation operator 'AT ALL', the speaker cancels a sloppy understanding of the use of the negation, as in (B2):

(B2) Ruti: Ein li Kesef BIXLAL (=afilu lo šekel)

Ruti: 'I don't have (any) money AT ALL!' (=not even a dollar)

'Following Kennedy \& McNally's approach to the interpretation of 'The Theater is empty tonight' in a scenario where a few people are present in the theater].

In (C), however, there exists a pre-supposition that a model is in fact pretty. But this discursive pre-supposition or common-ground background assumption is rejected. What the widening operator bixlal does, is to strengthen this rejected assumption:

(C) Dugmanit lo yafa bixlal

'A model not pretty at all!'

[http://bookcity.co.il/book.asp?id=29609]

Next, once the use of bixlal lo as a negation strengthener was semmanticized, bixlal lo could be used to strengthen predicative, descriptive negation with no background claims what so over, as in (D):

(D) Lihiyot me'amen ze bixlal lo pašut

'Being a coach is at all not easy

[Oded Katash, http://www.tlvtimes.co.il]

In (D14) there is no discursive pre-supposition that being a coach is easy (or not). The speaker is merely using a strong negation operator. 
1. Not in general (not so big in general)

2. Not AT ALL (o big)

This, in fact, serves as a bridging context which explains the shift of bixlal, from being an "in general" adverb into serving as a NPI to strengthen the negation. Therefore, from this point onwards, bixlal can be used as a NPI, widening an accessible negation in the discourse.

This use of bixlal can also occur without explicit negation operators, but with implicit negation only. This occurs in cases where there is use of a "negatively charged" word, such as different, or separate etc. In addition, bixlal as a NPI can also occur in conditional constructions (11) and in question constructions (12), which are known environments for hosting NPI ('Downward Entailing Contexts')7:

7 See Ruth Burstein (2004): all about questions that do not ask

(11) Mcati po et 'inyanay svuxim ve-hakol be-'irbuvia [..] ve-hineny 'osek be-berur ha-xešbonot- 'im bixlal yihiye efšar levareram

'I have found here my business messy and everything in disorder [..] and I engage in clarifying the bills- if at all it is going to be possible to clarify them'

[Ahad Ha'am's letter to Mordechai Ben Hillel Ha-Kohen, Warsaw, March 19, 1897, Tsirkin-Sadan, 2015]

(12) Kešem še-'ein anu 'itanu yode'a ma mikol ha-ma'asim hapnimiyim šel ota erec beštey hašanim ha'axronot, eix bixlal na'asim šam kol hadvarim ve-im hem na'asim

'Just like nobody knows what among all these internal affairs of that country in the last two years, how everything is even done over there and if it is done'

[Yosef Haim Brener,1920]

In (11), it is implied that it might be the case that clarifying the bills would not be possible in the first place. In (12) it is implied that the speaker does not know how internal affairs are done in that nation, and is not aware of how things are done (if they are done) in the first place. 
V. 6 (2)

10-28

jul/dez

2016

This implied negation in (11-12) is what Ladusaw (1996) calls 'Negatively Biased'. The negation in those examples is implied.

Since its first use in the $19^{\text {th }}$ century, bixlal has been increasingly popular, as can be seen in (2). This graph shows the use of bixlal lo from the year 1900 to the 1950s. Nowadays, bixlal as a NPI in used in almost $60 \%$ of bixlal's occurrences in general (859 cases were examined in the Tel-Aviv University Corpus (MA'AMAD).

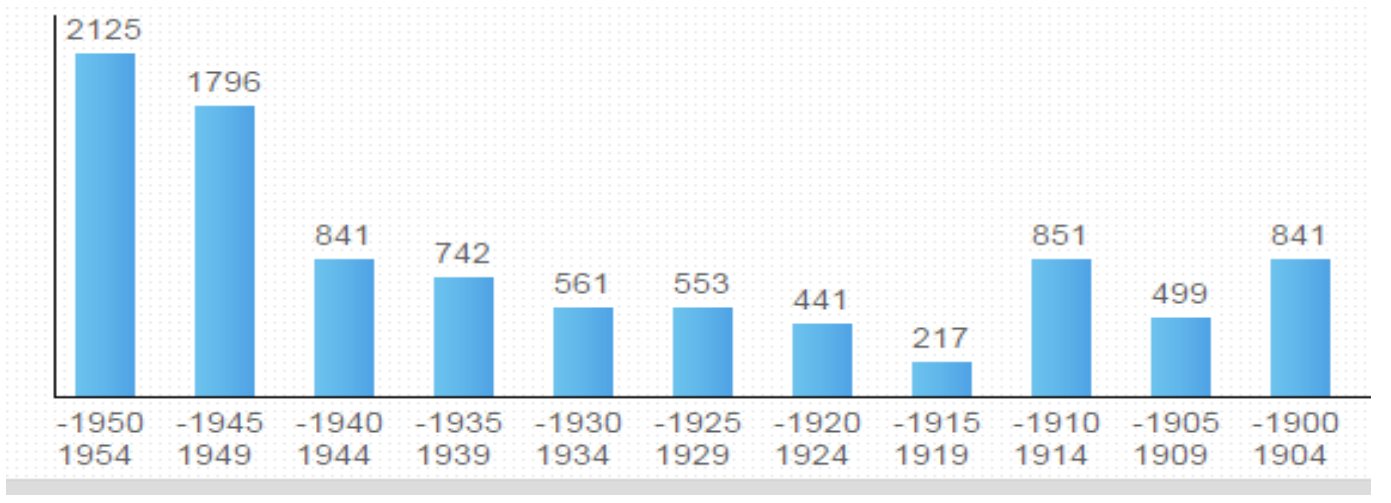

\section{Graph 2 - the use of bixlal lo from the year 1900 to the 1950 s}

\section{Stage IV: The Rectification Construction:}

'bixlal lo $\mathbf{X}$, elaY' ('not at all/even $\mathbf{X}$, but $\mathbf{Y}$ ')

In Modern Hebrew (20 ${ }^{\text {th }}$ century), there is initial evidence for the use of the Rectification Construction, as in $(13)^{8}$ :

(13) Nimtsa še hasrefa bixlal lo hitxila be-

Šetax ISRAEL, ela be-šetax HA-HEFKER

'It has been found out that the fire actually did not start in the ISRAELI territory, but in NO MAN'S LAND'

[ma'ariv, October 21 $1^{\text {st }}, 1954$ ]

The Rectification Construction is composed of four parts9:

8 There is no evidence of the use of the Rectification construction ('bixlal lo X, ela Y') prior to Modern Hebrew. There is, however, the use of the frequent Talmudic 'ein biklal ela ma šebifrat', (with an existential negation operator), whose interpretation is 'not in the rule, but only its specifics'. No evidence at all is given to the occurrence of the Rectification construction with bixlal as a NPI.

9 Mann and Thompson (1985) have defined relations within parts of texts and have named the ' not $\mathrm{x}$, but $\mathrm{y}$ ' construction the antithesis construction, which is composed of a satellite('not $\mathrm{x}$ ) and a nucleus (but $\mathrm{y}$ '). 
A. An accessible pre-claim or pre-supposition in the discourse $[\mathbf{X}]$

B. Satellite: The rejection of ' $\mathrm{X}$ '

C. Corrective ela (but): the connective/mediator between the satellite and the nucleus (D)

D. Nucleus: An alternative claim 'Y'

The rectification construction, as like other construction, was first compositional in nature. Within time it became a frequent discourse pattern, and thus, had become a construction ${ }^{10}$. As an element in a frequent discourse pattern bixlal could have function as a descriptivenegation operator. But once a construction had been created: 'bixlal lo $\mathrm{X}$, ela $\mathrm{Y}^{\prime}$, then bixlal is no longer used descriptively or predicatively, but rather meta-discursively, or argumentatively, as part of an externallinguistic reality (Anscombre \& Ducrot (1977). Within the construction, bixlal can no longer be focused, or stressed. The focus shifts to the rectified element ' $\mathrm{X}$ ' and the rectifying element ' $\mathrm{Y}$ '. It is a construction within the meta-discourse level, functioning mostly as a correction device of an accessible pre-claim or a pre-supposition in the discourse, either of the speaker herself (correcting herself in a monologue), of the addressee (correction within a dialogue), or a correction of an accessible pre-supposition within the discourse ${ }^{11}$. Bixlal's widening function at this stage in no longer solely of the scope of the negation, but rather of the contrast between the rectified element ' $X$ ' and the rectifying element ' $Y$ '.

\section{Stage V: Compactization}

bixlal lo $X$, ela $Y \quad$ bixlal $Y$

(at all not/not at all $X$, but $Y \quad$ actually $Y$ )

In late 1970s, early 1980s, there has been quite a syntacticdiscursively motivated dramatic development within the Rectification Construction.

Due to a frequent occurrence of bixlal within the rectification construction, a strong association between bixlal and the function of rectification was created, turning bixlal into a rectification marker (a 
V. 6 (2)

10-28

jul/dez

2016 discourse marker of rectification). Once reinterpreted as rectification marker, it could be used to indicate rectification even in the absence of the complete construction, as in (14). We shall further argue that this had been made possible in two sub-stages:

A: bixlal as a NPI gradually "taking on negation", as in other Jespersen's Cycle NPIs. As a result, the explicit rejection operator lo, along with the rejected element ' $\mathrm{X}$ ', had been left for inference. Unlike other Jespersen's cycles, here bixlal is constructionally argumentative and therefore takes on the rejection of the rectified element and not negation per-se.

B: Ela as a connector (mediator) between the rejected ' $\mathrm{X}$ ' and its replacement alternative ' $\mathrm{Y}$ ', is left for inference as well. This happened due to the fact that ela in Modern Hebrew functions as a NPI as well and needs an explicit negation operator in order to occur ${ }^{12}$. In addition, once the rejected element is left for inference, there is no need of a 'mediator' since there are no longer two explicit elements to mediate between. This use of bixlal is often translated in previous research as actually ${ }^{13}$.

(14): Zo Ha-drex le-kahir. Haderex le-kantara hi bixlal ba-kivun

Ha-hafux!

'This is the road to Cairo. The road to Qantara is actually in the other direction!'

[ma'ariv, March 31st, 1980]

We argue that this quite dramatic construction-reduction has been made possible due to 'discourse coherency'. It is more coherent within a dialogue to first reject an accessible pre-claim or an accessible pre-supposition in the discourse and only then justify its rejection by providing an alternative, rectifying element $t^{14}$.

Speakers always have the option of simply providing an alternative claim directly within the discourse, thus implying rectification. But

12 For more about the grammaticization path of ela (but) and its function in the different stages of Hebrew see Bardenstein (forthcoming).

13 See Migron (2003), Greenberg and Khrizman (2012), Sevi and Kadmon (2014), Tsirkin-Sadan 2015.

14 See Du-Bois (2015) for more about 'dialogic syntax'. 
this option (which is sometimes taken by speakers) is less 'discourse coherent'. Interestingly so, the reduced construction 'bixlal Y', "kills two birds in one shot". On the one hand, it provides a short rectification within the discourse, while on the other hand signaling the addressee that rectification is about to occur using bixlal as a discourse marker, or rectification marker. Another Modern Hebrew example (15), from the year 2015 demonstrates this 'reduced-use' of bixlal:

(15) Ha-rofi'm nidhamu! Ha-gidul ha-sartani hu bixlal ka'akua

'The doctors were astounded! The tumor is actually a tattoo!' [Walla health, 22.5.15]

\section{Stage VI: Widened Contrast Marker}

We argue that the use of bixlal in the last two years (2015-2016) has risen greatly (as shown in (3), due to the fact that it had been transformed into a "free" contrast marker between two elements in the discourse, no longer depending on rectification relation between those elements. i.e, the first element ' $X$ ' is no longer rejected and substituted with another alternative ' $\mathrm{Y}$ '. What bixlal does in this stage is simply mark and widen the contrast between two elements within the context. Therefore, bixlal still functions as a widener, but this widening relation is not dependant on the relation of rectification, but only on the relation of contrast between two elements in the discourse. For example, (16) was said about a psychiatrist who was hospitalized herself in a mental hospital. The use of bixlal in (16) widens the contrast between the element 'doctor' and the element 'patient' in this context.

Graph 3 - bixlal's occurrence between the years 2000-2016.

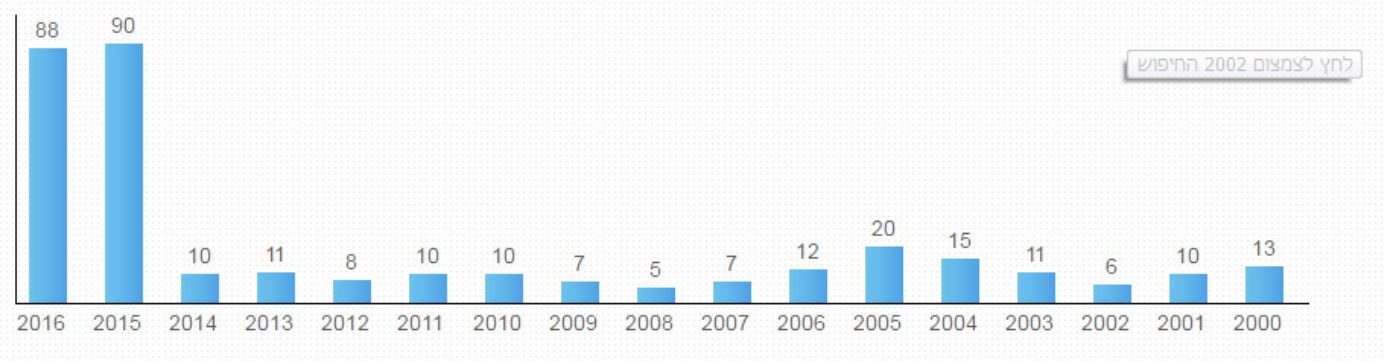


v. 6 (2)

10-28

jul/dez

2016
(16) Ha-rof'a še-la hayta bixlal ha-metupelet še-la

'Her DOCTOR was actually/in fact herPATIENT!'

[Lady Globes, December, 2014]

As evident in (16b), since bixlal is a sentential adverbial, it can always occur following the contrasted elements, still functioning as a marker and a widener of contrast.

(16b) Ha-rof'a še-la hayta ha-metupelet še-la bixlal 'Her doctor was her patient in fact/actually'

In the phonological arena, since bixlal has been much more frequently used, the pronunciation of bixlal has also changed, especially in informal speech, and in colloquial Hebrew speakers tend to shorten it into something like "b(e)xlal", in order to widen such contrast .

Ziv (2012) claims, the use of bixlal might convey disapproval. This use of bixlal translates as 'anyway', as in (17):

(17) matay habxina hazot bixlal

'When is this exam anyway?'

[Ziv, 2012]

\section{Stage VII: widened Contrast marker + NPI}

As a cyclic closer, bixlal can occur twice in the same sentencefirst as a contrast marker and secondly as a NPI. This is exemplified in (18):

(18) Menaše bixlal ein lo kešer le-ze bixlal 'Menaše actually has nothing to do with it at all' [http://www.tora-manhiga.org.il/show.asp?id=39569]

We argue that in (18), the first bixlal is a sentential adverbial, scoping over the entire sentence, and the second bixlal is a NPI, widening the scope of the negation ('nothing'), thus strengthening it. Since bixlal came to mark contrast within the discourse relatively recently, examples like (18) are quite rare. We could only find two such examples in our corpus. 


\section{Conclusions}

This article has presented the Rectification Cycle of bixlal in Hebrew, whose persistence function is widening ("once a widener, always a widener"). It is WHAT is being widened that changes. This cycle is in fact unidirectional and therefore it is actually more like a continuous spiral, ever changing.

We have shown in this article that bixlal's diachronic semantic change is motivated pragmatically via the operator's function, in this case- widening. From a categorical widener, biklal became a generalizing operator and a NPI, widening the scope of the negation. Then, it occurred within the Rectification Construction in which it widened the contrast between the rejected element ' $\mathrm{X}$ ' and its provided alternative ' $\mathrm{Y}$ '. In addition, another motivation for change is bixlal's frequent interaction with the negation, which has created a strong association between bixlal and the function of negation, or rejection. Within the Rectification construction, bixlal did not only "take on negation", as in various languages discussed by Jespersen (1917), but actually "took on rectification" and became a rectification marker. As discussed above, this has allowed the use of bixlal as a general contrast marker, creating the possibility of two bixlals to co-occur, each in a different use, closing up the circle, or more precisely, the spiral.

A similar cycle (or spiral) of rectification is also evident with other sentential adverbials in Hebrew (such as kvar (already) and davka (actually)). We shall conduct a thorough examination of those adverbials in future research. From a brief cross-linguistic examination, it is evident that this path of grammaticization has probably occurred in other languages such as Russian voobŝe and Polish vogule. These two languages share all of the different meanings of bixlal. A historical examination is in need to diachronically provide evidence for such analysis.

In addition, it might be the case that non-widening elements which have been used to strengthen negation have evolved into rectification markers. Among which are English actually which can be used to rectify an accessible pre-claim or a pre-supposition in the discourse, as in (19):

(19) According to a new study published in the Journal of marketing research, intrusive advertising may actually be 
V. $6(2)$

10-28

jul/dez

2016
BAD for business

[https://contently.com/strategist/2016/06/07/studyshows-publishers-actually-lose-money-running-badads]

In (19), a discourse pre-supposition that advertising is good for business is rejected and substituted for a claim that intrusive advertising might actually be bad for business. English actually shall also be examined diachronically in future studies. In addition, though English at all has evolved similarly to bixlal in its initial stages (see example (20)), at all cannot be used as a reduced (compact) rectification marker or a contrast marker (yet).

(20) Trump's official position is that the star on the image was not a star of David at all, but rather a "Sheriff's star" or perhaps just a "plain star"

[http://www.vox.com/2016/7/5/12095130/donald-trumpanti-semitism]

In (20), following the famous poster in which Hillary Clinton was shown with a star which was perceived to be a Star of David, Trump rejected that claim and provided an alternative which claimed that the star on the image was a plain star, or a sheriff's star.

In English, the connector or mediator between the satellite and the nucleus of the Rectification Construction can be but, but rather (20) or rather than (21), among other rectificational options.

(21) Dishonest media is trying their absolute best to depict a star in a tweet as the Star of David rather than a Sheriff's Star, or plain STAR!

[https://twitter.com/realdonaldtrump/status/749961528422625281]

Lastly, taking a closer look at examples such as (232-24) reveal that certain adverbials such as English just or Hebrew rak (just/only) might function as "intensifying downtoners" - on the one hand downtoning the rectifying element, or the nucleus of the construction as 'just a plain start' in (20), and on the other hand, widening the contrast between the rejected claim and its alternative. Thus, function as well as widening adverbials.

In future studies we intend to investigate all of the above. The 
function of rectification, which is one of the most common discourse constructions in Hebrew (AZAR, 1999) seems fascinating and calls for more elaborative analysis.

\section{References}

ANSCOMBRE, Jean-Claude; DUCROT, Oswald. Deux mais en français? Lingua 43 (1): 23-40, 1977.

ARIEL, Mira. Pragmatics and Grammar. Cambridge: Cambridge University Press, 2008

AZAR, Moshe. Mishnaic ela, a syntactic, semantic, pragmatic investigation. In: The world Congress of Judaic studies, 8, D, 11-14, 1981.

AZAR, Moshe. Argumentative constructions. In: Ben-Shachar, Rina; Rina and Gideon Tuti (eds). The Hebrew is a living language $\mathbf{b}$. Tel-Aviv: The united collection, 9-23, 1999

BURSHTEIN, Ruth. "On questions that don't ask" (Queclarative)". Eytan Zemarin Book, Jerusalem, The David Yalin education College .459-502, 2004.

DAHL, Osten. "Typology of sentence negation". Linguistics, 17: 79-106, 1979.

GOLDBERG, Adele. E. Constructions: A Construction Grammar approach to argument structure. Chicago: University of Chicago press, 1995.

GREENBERG, Yael; KHRIZMAN, Keren. "Bixlal - a General Strengthening Operator." Proceedings of IATL 27, 2012.

GREENBERG, Yael; ORENSTEIN, Dina. "Hebrew exclusive particles and the distinction between Roothian and 'internal' alternatives". Proceedings of IATL 29, 2014.

JESPERSEN, Otto. Negation in English and other languages. Historiskfilologiske Meddelelser 1.Copenhagen: A. F. Høst, 1917.

KADMON, Nirit; SEVI, Aldo. "Nuclear Accent and Lexical Meaning: The Case of bixlal." Presentation at Workshop on Focus Sensitive Expressions from a Cross Linguistic Perspective, Bar Ilan University, Ramat- Gan, 2014.

LADUSAW, William .'Negation and Polarity Items.' In The Handbook of Contemporary Semantic Theory, Shalom Lappin (ed.), 321-341, Oxford: Blackwell, 1996.

MANN, William C.; THOMPSON A, Sandra. Rhetorical Structure Theory: towards a functional theory of text organization. Text 8 (3), p. 243-281, 1988. This is an abridges version of Man \& Thompson (1985).

MASCHLER, Yael (2009). Metalanguage in Interaction: Hebrew discourse markers. Amsterdam: John Benjamins, 2009.

MIGRON, Hagit. "ma kore po Bixlal? " handout of a talk in HU, 2003. 
v. 6 (2) 10-28 jul/dez 2016
SPERBER, Dan; WILSON, Deirdre. Relevance. Oxford: Blackwell, 1986/1995.

TRAUGOTT, Elizabeth. The grammaticalization of NP patterns, in: Alexander Bergs Gabriele Diewald (eds). Trends in Linguistics : Constructions and language change, 2008.

TSIRKIN-SADAN, Avigail. Inheritance and Slavic contact in the polysemy of bixlal, in: Journal of Jewish Languages special issue on Modern Hebrew and Its Contact Languages, in cooperation with the Mandel Scholion Research Group on the Emergence of Modern Hebrew, 2015.

ZIV, Yael. "How many bixlals are there anyway?". Research in the new Hebrew and the Jewish languages, Carmel publications in honor of Orah Shwatswald. P.259-270., 2012.

Recebido em: 25 de ago. de 2016. Aceito em: 14 de dez. de 2016. 